\title{
Amaricoccus gen. nov., a Gram-Negative Coccus Occurring in Regular Packages or Tetrads, Isolated from Activated Sludge Biomass, and Descriptions of Amaricoccus veronensis sp. nov., Amaricoccus tamworthensis sp. nov., Amaricoccus macauensis sp. nov., and Amaricoccus kaplicensis sp. nov.
}

\author{
A. M. MASZENAN, ${ }^{1}$ R. J. SEVIOUR, ${ }^{1 *}$ B. K. C. PATEL, ${ }^{2}$ G. N. REES,${ }^{3} \dagger$ AND B. M. MCDOUGALL ${ }^{1}$ \\ Biotechnology Research Centre, La Trobe University, Bendigo, Victoria 3550, ${ }^{1}$ Faculty of Science and Technology, \\ Griffith University, Nathan, Brisbane, Queensland $4111,{ }^{2}$ and Faculty of Applied Science, \\ University of Canberra, Belconnen, Australian Capital Territory 2616, ${ }^{3}$ Australia
}

\begin{abstract}
Three isolates of gram-negative bacteria, strains Ben $102^{\mathrm{T}}$, Ben $103^{\mathrm{T}}$, and Ben $104^{\mathrm{T}}$, were obtained in pure culture by micromanipulation from activated sludge biomass from wastewater treatment plants in Italy, Australia, and Macau, respectively. These isolates all had a distinctive morphology; the cells were cocci that usually were arranged in tetrads. Based on this criterion, they resembled other bacteria from activated sludge previously called " $G$ " bacteria. On the basis of phenotypic characteristics and the results of $16 \mathrm{~S}$ ribosomal DNA sequence analyses, the three isolates were very similar to each other, but were sufficiently different from their closest phylogenetic relatives (namely, the genera Rhodobacter, Rhodovulum, and Paracoccus in the $\alpha$ subdivision of the Proteobacteria) to be placed in a new genus, Amaricoccus gen. nov. Each of the three isolates represents a new species of the genus Amaricoccus; strains Ben $102^{\mathrm{T}}$, Ben $103^{\mathrm{T}}$, and Ben $104^{\mathrm{T}}$ are named Amaricoccus veronensis, Amaricoccus tamworthensis, and Amaricoccus macauensis, respectively. An isolate designated Ben $101^{\mathrm{T}}$, which was isolated independently by Cech and Hartman in Kaplice, Czech Republic, was also characterized and belongs to the same genus. We propose that the isolate of Cech and Hartman should be placed in another new species, Amaricoccus kaplicensis.
\end{abstract}

Most industrial and domestic wastewaters are treated by the activated sludge process before disposal. However, little is known about the microbes present in these systems and their roles, a situation which reflects the inadequate methods used to study the activated sludge community $(1,4,25,40)$. In 1990 , Cech and Hartman (6) described large numbers of gram-negative cocci arranged in tetrads which appeared in a laboratory scale treatment system fed with glucose. Cech and Hartman called these organisms " $G$ " bacteria, and although they were isolated in pure culture, these organisms were not identified (7). On the basis of the results of a few phenotypic tests and morphology, it was suggested that they might be members of the genus Methanosarcina in the domain Archaea (8). Routine microscopic examination of biomass samples from wastewater treatment plants located around the world revealed the presence of large numbers of organisms morphologically similar to the organisms described by Cech and Hartman (6). Because these bacterial morphotypes occur frequently in biomass samples from activated sludge treatment processes, we attempted to obtain several isolates of " $G$ "-like bacteria to determine their taxonomic status by a polyphasic taxonomic approach (38) and to determine their relationships to the original unidentified isolate of Cech and Hartman.

\section{MATERIALS AND METHODS}

Isolation and maintenance of bacterial strains. All of the strains whose sources are shown in Table 1 were grown on GS medium of Williams and Unz (42), which contained (per liter) $0.15 \mathrm{~g}$ of glucose, $0.50 \mathrm{~g}$ of $\left(\mathrm{NH}_{4}\right)_{2} \mathrm{SO}_{4}, 0.10 \mathrm{~g}$

* Corresponding author. Phone: 61-54-447459. Fax: 61-54-447476. E-mail: r.seviour@latrobe.edu.au.

† Present address: The Murray Darling Freshwater Research Centre, Albury, NSW 2640, Australia. of $\mathrm{CaCO}_{3}, 0.10 \mathrm{~g}$ of $\mathrm{Ca}\left(\mathrm{NO}_{3}\right)_{2}, 0.05 \mathrm{~g}$ of $\mathrm{KCl}, 0.05 \mathrm{~g}$ of $\mathrm{K}_{2} \mathrm{HPO}_{4}, 0.05 \mathrm{~g}$ of $\mathrm{MgSO}_{4} \cdot 7 \mathrm{H}_{2} \mathrm{O}, 0.187 \mathrm{~g}$ of $\mathrm{Na}_{2} \mathrm{~S} \cdot 9 \mathrm{H}_{2} \mathrm{O}, 15 \mathrm{~g}$ of bacteriological agar (Difco), and $1.0 \mathrm{ml}$ of a $10 \times$ vitamin stock solution. The vitamin stock solution contained (per liter) $1 \mathrm{mg}$ of calcium pantothenate, $1 \mathrm{mg}$ of niacin, $5 \times 10^{-3} \mathrm{mg}$ of biotin, $5 \times$ $10^{-3} \mathrm{mg}$ of cyanocobalamin, $5 \times 10^{-3} \mathrm{mg}$ of folic acid, $1 \mathrm{mg}$ of pyridoxine, $1 \mathrm{mg}$ of $p$-aminobenzoic acid, $1 \mathrm{mg}$ of cocarboxylase, $1 \mathrm{mg}$ of inositol, $1 \mathrm{mg}$ of thiamine, and $1 \mathrm{mg}$ of riboflavin. Three isolates, strains Ben $102^{\mathrm{T}}$, Ben $103^{\mathrm{T}}$, and Ben $104^{\mathrm{T}}$, were cultured from activated sludge biomass from plants in Verona, Italy, Tamworth, Australia, and Macau, respectively, after micromanipulation with a Skerman micromanipulator (35). Many attempts to isolate gram-negative " $G$ "like bacteria on a wide range of media routinely used for bacterial isolation from activated sludge samples were unsuccessful (32). Inoculated plates of GS medium were incubated at $25^{\circ} \mathrm{C}$ for 2 weeks, and the colony growth of the micromanipulated organisms was checked daily. Each colony was then streaked ou several times onto fresh GS medium to ensure its purity, which was confirmed by microscopy. Strain Ben $101^{\mathrm{T}}$ was a gift from J. S. Cech. All cultures were stored on GS medium in $20 \%$ glycerol at $-80^{\circ} \mathrm{C}$.

Phenotypic characterization. The substrate utilization patterns of all of the isolates were determined with the BIOLOG system (Special Diagnostic, Melbourne, Australia). Cells were grown on GS agar at $25^{\circ} \mathrm{C}$ for 5 days and then suspended in physiological saline to the turbidity standard recommended by the manufacturer. Inoculated GN and GP microplates were incubated at $25^{\circ} \mathrm{C}$ for $24 \mathrm{~h}$ and then examined by using an image analysis system consisting of a Panasonic video camera and video capture software (MediaStation, version 2.5; Ulead Systems, Inc., Torrance, Calif.) with a MIRO 20 video card. Each captured image was edited and analyzed by using the Sigmascan image analysis program software (Jandel Scientific Software, San Rafael, Calif.), which compensated for any color development in the control wells of the microtiter plates. Cells of each isolate were also inoculated onto API ZYM strips (Bio Mérieux, Lyon, France) that were incubated at $25^{\circ} \mathrm{C}$ for $4 \mathrm{~h}$, and the results were recorded as recommended by the manufacturer. Each isolate was characterized at least in duplicate. The Microbact 24E system (Oxoid, Melbourne, Australia) was used to determine selected biochemical properties of the strains, as described below. Catalase and oxidase tests and a test to determine motility by the hanging drop method were also performed with all of the isolates by using standard methods (36). Growth responses to temperature and $\mathrm{pH}$ were determined by using GS medium. The phenotypic data were analyzed by performing a numerical taxonomy analysis with simple matching coefficients $\left(\mathrm{S}_{\mathrm{sm}}\right)$ and the unweighted pair group with mathematical average (UPGMA) clustering algorithm (37) by using the NTSYS-pc software package, version 1.80 (Exeter Software, New York, N.Y.).

Preparation of specimens for scanning electron microscopy. The isolates used for scanning electron microscopy were fixed overnight in $3 \%$ glutaraldehyde in 
TABLE 1. Sources of the gram-negative isolates used in this study

\begin{tabular}{ccc}
\hline Strain & \multicolumn{1}{c}{ Source } & Date of isolation \\
\hline Ben $101^{\mathrm{T} a}$ & $\begin{array}{l}\text { Laboratory scale sequence batch reactor, } \\
\text { Kaplice, Czech Republic }\end{array}$ \\
Ben $102^{\mathrm{T}}$ & $\begin{array}{c}\text { Full-scale activated sludge plant treating } \\
\text { domestic waste, Verona, Italy }\end{array}$ & 27 March 1996 \\
Ben $103^{\mathrm{T}}$ & $\begin{array}{l}\text { Industrial plant treating malting waste, } \\
\text { Tamworth, Australia }\end{array}$ & 15 September 1995 \\
Ben $104^{\mathrm{T}}$ & $\begin{array}{c}\text { Full-scale activated sludge plant treating } \\
\text { domestic waste, Macau }\end{array}$ & 11 February 1996 \\
\hline
\end{tabular}

${ }^{a}$ This strain was kindly provided by J. S. Cech.

$0.1 \mathrm{M}$ phosphate buffer ( $\mathrm{pH} 7.0$ ). Cells were centrifuged, washed with phosphate buffer, and postfixed in $\mathrm{OsO}_{4}$ for $2 \mathrm{~h}$ before they were dehydrated in a graded acetone series ( 0 to $100 \%$ ). Dehydrated cells were then spread onto glass coverslips coated with a $2 \%$ ethanolic solution of 3-aminopropyltriethoxysilane. The coverslips were critical point dried, coated with gold, and then viewed with a Cambridge Stereoscan model 150 MK2 scanning electron microscope.

Determination of the 16S rDNA sequence. $16 \mathrm{~S}$ ribosomal DNA (rDNA) amplification and sequencing were performed for each isolate as described by Blackall (3). PCR-amplified products were purified by using a Magic Wizard purification kit (Promega, Annadale, Australia), and cycle sequencing reactions were performed with an Omnigene Hybaid thermal cycler (Intersciences, Melbourne, Australia) by using a Ready Reaction dye terminator kit (Applied Biosystems, Melbourne, Australia). The sequencing products were cleaned and precipitated as recommended by the manufacturer. After analysis, the sequences were aligned with the sequences of members of various genera of the domains Bacteria and Archaea as previously described by Patel et al. (30). Pairwise evolutionary distances were computed by the method of Jukes and Cantor (16) Dendrograms were constructed from evolutionary distances by using the neighbor-joining method, and a transversion analysis was performed as described by Patel et al. (30). Tree topology was examined by using 100 bootstrapped data sets. The computer programs used included SEQBOOT, DNADIST, FITCH, and CONSENSE, which are part of PHYLIP, version 3.51c (10).

$\mathbf{G}+\mathbf{C}$ content. DNA base composition was calculated following thermal denaturation of DNA isolated by using the modified Marmur methods described by Owen and Lapage (28).

Nucleotide sequence accession numbers. The $16 \mathrm{~S}$ rRNA gene sequences of strains Ben $101^{\mathrm{T}}$, Ben $102^{\mathrm{T}}$, Ben $103^{\mathrm{T}}$, and Ben $104^{\mathrm{T}}$ have been deposited in the GenBank database under accession no. U88041, U88043, U88044, and U88042, respectively.

\section{RESULTS}

Organism characteristics. Although we screened a wide range of media, including many media which have been used successfully in the past to culture activated sludge bacteria (32), only GS medium of Williams and Unz (42) supported the growth of Ben $102^{\mathrm{T}}$, Ben $103^{\mathrm{T}}$, and Ben $104^{\mathrm{T}}$. Many tetrads obtained from other plants did not grow on any of the media tested, including GS medium, and so could not be obtained in pure culture. All of the isolates had the same distinctive morphology; the coccoid cells were usually organized in tetrads. Figure 1 shows the morphology of the strains in activated sludge mixed liquor and axenic cultures. None of the organisms appeared to use the sulfide in the medium as an energy source, as indicated by the absence of any sulfur granules when the organisms were grown on GS medium. All of the isolates produced capsules, as revealed by the Duguid staining method (36), and none stained positive with Neisser stain (9), suggesting that the isolates do not accumulate polyphosphate granules. The average mean cell diameters of individual coccal cells were $1.8 \mu \mathrm{m}$ for Ben $102^{\mathrm{T}}$ and Ben $103^{\mathrm{T}}, 1.6 \mu \mathrm{m}$ for Ben $101^{\mathrm{T}}$, and $1.3 \mu \mathrm{m}$ for Ben $104^{\mathrm{T}}$. Strain Ben $101^{\mathrm{T}}$ was more pleomorphic than the other strains, while strain Ben $103^{\mathrm{T}}$ produced a fibril network that interconnected the individual tetrads (Fig. If and $h$ ), a morphological feature not observed with the other strains. The chemical composition of the interconnecting network is not known; it is probably not cellulosic in nature since cells did not exhibit any characteristic fluorescence when they were grown on GS agar containing calcofluor (22), whereas
Agrobacterium tumefaciens, which is known to produce cellulose fibrils (2), did fluoresce.

Physiological characteristics. The results obtained in the substrate utilization experiments performed with BIOLOG GN and GP systems showed that the four isolates studied had very similar carbon utilization patterns, although there were some differences (Table 2). All of the strains used dextrin, L-arabinose, D-arabitol, cellobiose, D-fructose, L-fucose, D-galactose, $\alpha$-D-glucose, $m$-inositol, maltose, D-mannitol, D-mannose, D-psicose, L-rhamnose, D-sorbitol, sucrose, D-trehalose, turanose, xylitol, methyl pyruvate, monomethyl succinate, $\alpha$ hydroxybutyric acid, $\beta$-hydroxybutyric acid, $\alpha$-ketobutyric acid, DL-lactic acid, succinic acid, succinamic acid, D-alanine, L-alanine, L-asparagine, L-glutamic acid, L-serine, maltotriose, palatinose, D-ribose, salicin, D-tegatose, D-xylose, D-lactic acid methyl ester, L-lactic acid, D-malic acid, L-malic acid, methyl succinate, pyruvic acid, $N$-acetyl-L-glutamic acid, and adenosine. None of the isolates utilized $\alpha$-cyclodextrin, $N$-acetyl-Dgalactosamine, i-erythritol, $\alpha$-D-lactose, lactulose, D-raffinose, D-glucosaminic acid, D-saccharic acid, sebacic acid, L-alanyl-glycine, glycyl-L-aspartic acid, L-histidine, L-leucine, L-ornithine, Lpyroglutamic acid, uridine, inulin, amygdalin, $\alpha$-methyl-D-galactoside, $\alpha$-methyl-D-mannoside, sedoheptulosan, stachyose, and UMP.

The API ZYM profiles obtained for the four isolates were similar, although some differences in the levels of activity of some of the enzymes were observed. All four strains possessed alkaline phosphatase, esterase, esterase-lipase, lipase, leucine arylamidase, valine arylamidase, acid phosphatase, naphtholAS-BI-phosphohydrolase, and $\alpha$-glucosidase activities. No cystine arylamidase, trypsin, chymotrypsin, $\alpha$-galactosidase, $\beta$ galactosidase, $\beta$-glucuronidase, $\beta$-glucosidase, $N$-acetyl- $\beta$-glucosaminidase, $\alpha$-mannosidase, or $\alpha$-fucosidase activity was detected in any of the strains.

The biochemical properties of the four strains as determined with Microbact systems were similar. Thus, all of the strains were nonmotile and oxidase positive and produced acid from glucose, mannitol, xylose, sorbitol, rhamnose, sucrose, and arabinose. None of the isolates produced acid from lactose or raffinose. Ornithine decarboxylase, urease, arginine dihydrolase, and $\beta$-galactosidase activities were not detected. None of the organisms produced $\mathrm{H}_{2} \mathrm{~S}$, indole, or acetoin. However, some differences were observed. Citrate utilization and lysine decarboxylase activity were recorded only with Ben $104^{\mathrm{T}}$, and all of the strains except Ben $102^{\mathrm{T}}$ possessed urease activity. Ben $102^{\mathrm{T}}$ was the only strain which was catalase negative. Nitrate reduction occurred only in Ben $101^{\mathrm{T}}$, which was the only strain examined which did not produce acid from inositol. Only Ben $102^{\mathrm{T}}$ produced acid from adonitol, and neither Ben $103^{\mathrm{T}}$ nor Ben $104^{\mathrm{T}}$ produced acid from salicin.

A numerical taxonomic analysis performed with all of the phenotypic data revealed that the four strains formed a tight cluster with each other at an $\mathrm{S}_{\mathrm{sm}}$ value of 0.75 with the UPGMA algorithm (Fig. 2). This grouping at a relatively high similarity level suggests that the organisms belong to a single genus (37). However, none of the isolates was linked to another isolate at an $\mathrm{S}_{\mathrm{sm}}$ value greater than 0.85 , which suggests that each of the isolates represents a different species of the same genus.

All of the strains grew at temperatures between 20 and $37^{\circ} \mathrm{C}$ and no growth occurred at 5,15 , and $45^{\circ} \mathrm{C}$. The optimal growth temperature was $25^{\circ} \mathrm{C}$. All of the isolates grew at $\mathrm{pH}$ values between 6.0 and 9.0 , and no growth occurred at $\mathrm{pH} 5.5$ or 9.3 .

DNA base composition. The DNA base compositions of Ben $101^{\mathrm{T}}$, Ben $102^{\mathrm{T}}$, Ben $103^{\mathrm{T}}$, and Ben $104^{\mathrm{T}}$ were $56,58,58$, and $63 \mathrm{~mol} \% \mathrm{G}+\mathrm{C}$, respectively. 

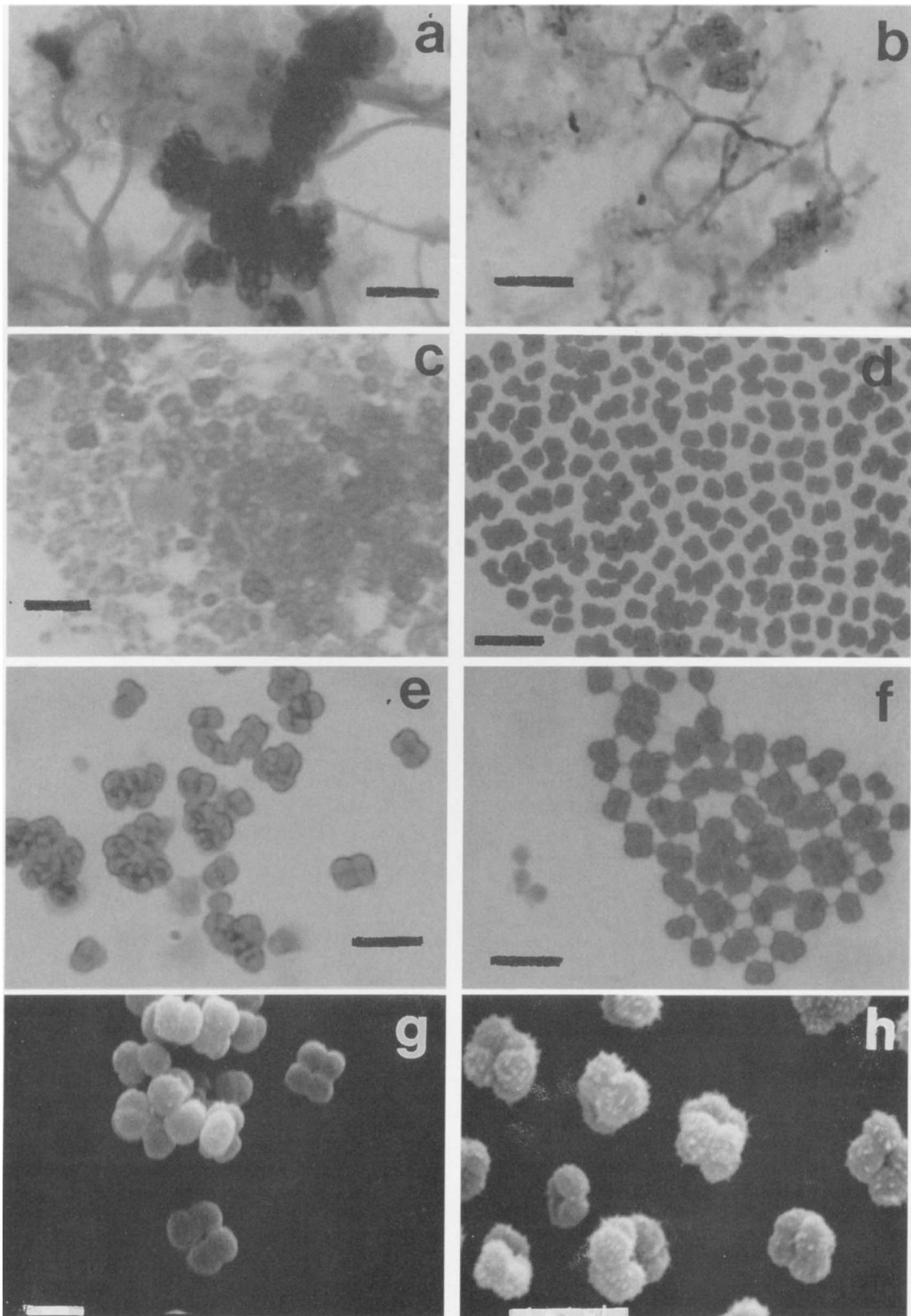

FIG. 1. Morphology of gram-negative coccal isolates obtained from activated sludge samples. (a) Clusters of cells arranged in tetrads in activated sludge biomass from Verona, Italy. (b) "G"-like cells arranged in tetrads in activated sludge biomass from Macau. (c) Light micrograph of strain Ben $101^{\mathrm{T}}$ stained with Gram stain. (d) Light micrograph of strain Ben $104^{\mathrm{T}}$ stained with Gram stain. (e) Light micrograph of a pure culture of strain Ben $102^{\mathrm{T}}$ tetrads from Verona, Italy. (f) Light micrograph of a pure culture of strain Ben $103^{\mathrm{T}}$ from Tamworth, Australia, showing the tetrads and microfibrillar connections. (g) Scanning electron micrograph of strain Ben $102^{\mathrm{T}}$, showing the characteristic tetrad morphology. (h) Scanning electron micrograph of strain Ben $103^{\mathrm{T}}$, showing tetrads with remnants of surface microfibrils. (a through $\mathrm{f}$ and $\mathrm{h}$ ) Bars $=4 \mu \mathrm{m}$. (g) Bar $=2 \mu \mathrm{m}$. 
TABLE 2. Carbon substrate utilization patterns used to differentiate the four new gram-negative isolates with the Biolog GN and GP Microplate system

\begin{tabular}{|c|c|c|c|c|}
\hline \multirow{2}{*}{ Carbon source } & \multicolumn{4}{|c|}{ Utilization by: } \\
\hline & Ben $101^{\mathrm{T}}$ & Ben $102^{\mathrm{T}}$ & Ben $103^{T}$ & Ben $104^{\mathrm{T}}$ \\
\hline Glycogen & $+^{a}$ & + & - & + \\
\hline Tween 40 & - & - & + & - \\
\hline Tween 80 & - & + & + & - \\
\hline$N$-Acetyl-D-glucosamine & + & - & + & + \\
\hline Adonitol & - & + & - & - \\
\hline Gentiobiose & - & + & + & + \\
\hline D-Melibiose & - & - & + & - \\
\hline$\beta$-Methyl-D-glucoside & - & + & + & + \\
\hline D-Glucuronic acid & - & - & - & + \\
\hline Acetic acid & + & + & - & + \\
\hline cis-Aconitic acid & + & - & - & + \\
\hline Citric acid & - & - & - & + \\
\hline Formic acid & + & + & - & + \\
\hline D-Galactonic acid lactone & + & - & - & - \\
\hline D-Galacturonic acid & - & - & + & - \\
\hline D-Gluconic acid & + & - & + & + \\
\hline$\gamma$-Hydroxybutyric acid & + & - & + & + \\
\hline p-Hydroxyphenylacetic acid & - & - & - & + \\
\hline Itaconic acid & - & - & - & + \\
\hline$\alpha$-Ketovaleric acid & + & - & - & - \\
\hline Malonic acid & - & - & - & + \\
\hline Propionic acid & + & - & - & + \\
\hline Quinic acid & - & - & - & + \\
\hline Bromosuccinic acid & + & + & - & + \\
\hline Glucuronamide & - & - & - & + \\
\hline Alaninamide & + & + & - & + \\
\hline L-Aspartic acid & + & + & - & + \\
\hline Glycyl-L-glutamic acid & - & + & - & - \\
\hline$\beta$-Methyl-D-galactoside & - & - & - & + \\
\hline Fructose-6-phosphate & - & + & - & + \\
\hline Hydroxy-L-proline & - & - & - & + \\
\hline L-Phenylalanine & - & - & - & + \\
\hline L-Proline & - & + & - & + \\
\hline$\alpha$-Ketoglutaric acid & - & - & + & - \\
\hline D-Serine & + & - & - & + \\
\hline$\alpha$-Ketobutyric acid & + & + & - & + \\
\hline L-Threonine & - & + & - & + \\
\hline DL-Carnitine & - & + & - & + \\
\hline$\gamma$-Aminobutyric acid & - & - & - & + \\
\hline Urocanic acid & - & - & + & + \\
\hline Inosine & + & + & - & + \\
\hline Thymidine & + & + & - & + \\
\hline Phenylethylamine & + & + & - & + \\
\hline Putrescine & - & - & - & + \\
\hline 2-Aminoethanol & - & - & - & + \\
\hline 2,3-Butanediol & - & + & - & - \\
\hline Glycerol & + & - & + & + \\
\hline DL- $\alpha$-Glycerol phosphate & - & - & - & + \\
\hline Glucose 1-phosphate & - & + & - & + \\
\hline Glucose 6-phosphate & - & + & - & + \\
\hline$\beta$-Cyclodextrin & - & + & + & - \\
\hline Mannan & - & + & + & - \\
\hline$N$-Acetyl mannosamine & - & + & - & - \\
\hline Arbutin & + & + & - & + \\
\hline D-Melezitose & - & + & - & + \\
\hline 3-Methyl glucose & - & + & + & - \\
\hline$\alpha$-Methyl-D-glucoside & - & + & - & - \\
\hline Lactamide & - & + & + & + \\
\hline $2^{\prime}$-Deoxyadenosine & + & + & - & + \\
\hline AMP & - & + & - & + \\
\hline TMP & - & + & - & + \\
\hline
\end{tabular}

${ }^{a}+$, utilized;,- not utilized.

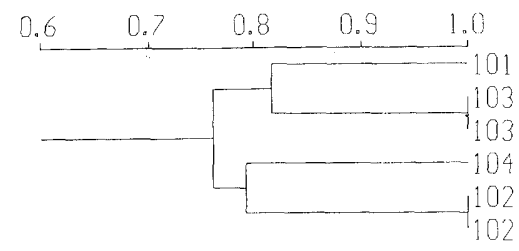

FIG. 2. Dendrogram based on an $\mathrm{S}_{\mathrm{sm}}$-UPGMA numerical taxonomy analysis of the phenotypic characteristics of the four new strains. Strains Ben $103^{T}$ and Ben $102^{\mathrm{T}}$ were analyzed in duplicate.

Phylogenetic characteristics. We determined almost complete sequences of the $16 \mathrm{~S}$ rRNA genes of strain Ben $101^{\mathrm{T}}$ $\left(1,410\right.$ bases), strain Ben $102^{\mathrm{T}}$ (1,431 bases), strain Ben $103^{\mathrm{T}}$ ( 1,424 bases), and strain Ben $104^{\mathrm{T}}$ (1,411 bases); these sequences corresponded to positions 9 to 1513,8 to 1514,13 to 1512 , and 8 to 1507 , respectively, of the Escherichia coli sequence according to the nomenclature of Winker and Woese (43). Sequence comparisons revealed that the sequences were related to each other at an average level of similarity of $96.6 \%$ (Table 3 ).

A phylogeny based on the $16 \mathrm{~S}$ rRNA analysis data indicated that all four isolates were members of the $\alpha$ subdivision of the Proteobacteria $(20,27)$ in the domain Bacteria. The presence of the oligonucleotide signature 5' CUGGCUCAGAACGA ACG $3^{\prime}$ at positions 19 to 35 ( $E$. coli numbering according to the nomenclature of Winker and Woese [43]) confirmed the relationship of the new strains to the $\alpha$ subdivision of the Proteobacteria $(20,27)$. The four new isolates formed a new branch within the subdivision and were almost equidistant from members of the genera Paracoccus $(18,39)$, Rhodobacter $(14,15)$, and Rhodovulum $(12,13,15)$, with an average similarity value of $91 \%$ (Table 3 ). The genus Roseobacter $(33,34)$ was less closely related to the new isolates (level of similarity, $88 \%$ ) and was not included in the phylogenetic analyses; this relationship was robust, as indicated by the high confidence values obtained in the bootstrap analysis. The positions of the four new isolates on the phylogenetic tree were also stable and did not change when a transversion analysis was performed (Fig. 3).

\section{DISCUSSION}

Our knowledge of the microbiology of activated sludge is incomplete due to a lack of information concerning the precise taxonomic status of many of the organisms present in the biomass and their roles in the process $(1,4,25,40)$. Pure cultures are necessary to address these issues, and the results of this study reinforced the view that there are many novel organisms still to be discovered in the complex activated sludge ecosystems $(4,5,11,19,21,23,24,31)$. Many gram-positive cocci, including members of the genera Micrococcus (17, 29, 41), Microlunatus (26), and Microsphaera (44), have been isolated from activated sludge samples and cultured. Recent studies in our laboratory have resulted in the isolation of several gram-positive cocci occurring in tetrads which belong to none of these genera and represent previously undescribed genera $(20 a, 37 a)$. The data suggest that there is considerable diversity among the cocci in activated sludge systems, and the functions and significance of these organisms in the processes are likely to be different.

The results of our phylogenetic analysis indicate that four isolates, strains Ben $101^{\mathrm{T}}$, Ben $102^{\mathrm{T}}$, Ben $103^{\mathrm{T}}$, and Ben $104^{\mathrm{T}}$, form a coherent cluster and are only distantly related to the genera Paracoccus $(18,39)$, Rhodovulum $(12,13,15)$, and 
TABLE 3. Levels of 16S rDNA similarity for members of the genus Amaricoccus within the radiation of the Rhodobacter group and other taxa belonging to the $\alpha$ subclass of the Proteobacteria $\%$ rDNA similarity ${ }^{a}$

Strain

\begin{tabular}{|c|c|c|c|c|c|c|c|c|c|c|c|c|c|c|c|c|c|c|c|c|c|c|}
\hline \multicolumn{23}{|c|}{$\%$ rDNA similarity ${ }^{a}$} \\
\hline 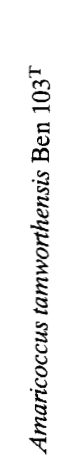 & 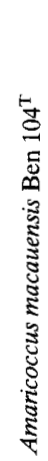 & 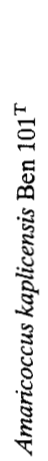 & 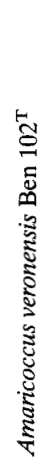 & 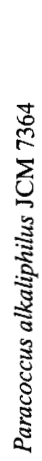 & 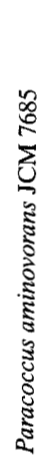 & 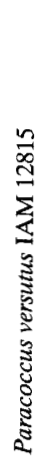 & 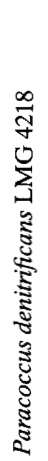 & 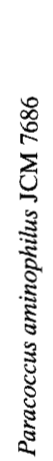 & 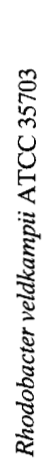 & 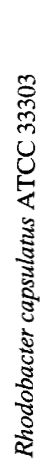 & 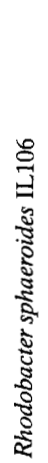 & 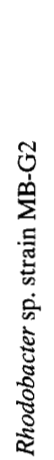 & 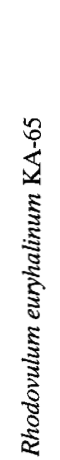 & 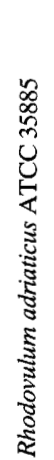 & 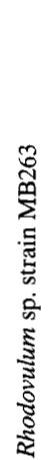 & 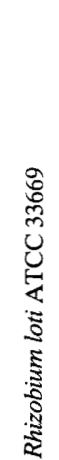 & 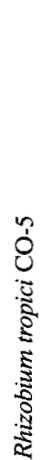 & 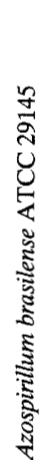 & 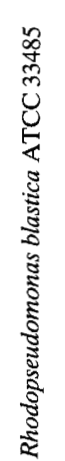 & 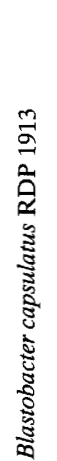 & 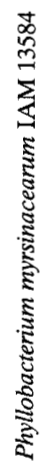 & 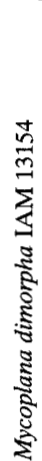 \\
\hline
\end{tabular}

Amaricoccus tamworthensis Ben $103^{\mathrm{T}}$

100

Amaricoccus macauensis Ben $104^{\mathrm{T}}$

Amaricoccus kaplicensis Ben $101^{\mathrm{T}}$

Amaricoccus veronensis Ben $102^{\mathrm{T}}$

Paracoccus alkaliphilus JCM 7364

Paracoccus aminovorans JCM 7685

Paracoccus versutus IAM 12815

Paracoccus denitrificans LMG 4218

Paracoccus aminophilus JCM 7686

Rhodobacter veldkampii ATCC 35703

95.8

$96.3 \quad 95.8$

$\begin{array}{lll}95.9 & 98.1 & 95.8 \\ 91.0 & 92.2 & 91.9\end{array}$

$\begin{array}{llll}91.0 & 92.2 & 91.9 & 91.9\end{array}$

$\begin{array}{lllll}92.0 & 91.7 & 92.5 & 91.0 & 96.4\end{array}$

$\begin{array}{llllll}91.2 & 92.1 & 91.8 & 92.0 & 96.2 & 96.0\end{array}$

$\begin{array}{lllllll}91.4 & 92.1 & 92.4 & 91.9 & 95.8 & 96.3 & 99.3\end{array}$

$\begin{array}{llllllll}90.7 & 91.0 & 91.5 & 90.5 & 97.1 & 96.8 & 95.3 & 95.8\end{array}$

$\begin{array}{lllllllll}92.6 & 92.9 & 93.1 & 92.5 & 93.8 & 94.8 & 93.7 & 93.8 & 93.2\end{array}$

Rhodobacter capsulatus ATCC 33303

$\begin{array}{lllllllll}92.0 & 92.4 & 92.4 & 92.4 & 93.6 & 93.2 & 93.7 & 93.4 & 91.8\end{array}$

Rhodobacter sphaeroides IL106

Rhodobacter sp. strain MB-G2

Rhodovulum euryhalinum KA-65

Rhodovulum adriaticus ATCC 35885

Rhodovulum sp. strain MB263

$\begin{array}{lllllllllll}93.0 & 93.2 & 93.3 & 93.0 & 92.9 & 93.6 & 93.1 & 93.7 & 92.8 & 95.3 & 95.2\end{array}$

$\begin{array}{llllllllllll}91.4 & 91.6 & 91.9 & 91.7 & 91.4 & 91.4 & 91.1 & 91.5 & 91.4 & 94.4 & 92.7 & 93.6\end{array}$

$\begin{array}{lllllllllllll}90.7 & 91.2 & 91.4 & 91.0 & 91.5 & 91.8 & 91.9 & 92.5 & 90.9 & 94.2 & 92.9 & 94.0 & 97.0\end{array}$

$\begin{array}{llllllllllllll}91.0 & 90.6 & 91.8 & 90.6 & 91.4 & 92.3 & 91.8 & 92.5 & 92.3 & 93.3 & 91.7 & 93.7 & 93.7 & 94.0\end{array}$

Rhizobium loti ATCC 33669

Rhizobium tropici CO-5

Azospirillum brasilense ATCC 29145

Rhodopseudomonas blastica ATCC 33485

Blastobacter capsulatus RDP 1913

$\begin{array}{lllllllllllllll}91.0 & 91.1 & 92.1 & 90.9 & 92.2 & 92.2 & 92.2 & 92.8 & 92.4 & 94.3 & 93.6 & 93.7 & 96.6 & 95.3 & 95.4\end{array}$

$\begin{array}{lllllllllllllllll}88.9 & 88.6 & 89.5 & 88.3 & 89.2 & 90.2 & 90.4 & 90.4 & 90.1 & 89.3 & 89.1 & 89.8 & 89.2 & 88.9 & 89.3 & 90.2\end{array}$

$\begin{array}{llllllllllllllllll}87.2 & 87.0 & 87.5 & 87.6 & 86.8 & 86.8 & 86.9 & 86.8 & 86.8 & 87.5 & 86.1 & 89.5 & 87.5 & 87.8 & 88.2 & 88.4 & 94.1\end{array}$

$\begin{array}{llllllllllllllllllll}87.2 & 87.0 & 87.5 & 87.6 & 86.8 & 86.8 & 86.9 & 86.8 & 86.8 & 87.5 & 86.1 & 87.3 & 88.3 & 87.7 & 86.4 & 87.2 & 86.1 & 87.0\end{array}$

$\begin{array}{lllllllllllllllllllll}87.3 & 87.2 & 87.2 & 92.7 & 92.3 & 92.1 & 93.1 & 92.9 & 91.4 & 94.8 & 94.7 & 95.2 & 93.9 & 93.5 & 91.7 & 93.0 & 89.1 & 88.7 & 87.5\end{array}$

Mycoplana dimorpha IAM 13154

$\begin{array}{lllllllllllllllllllll}90.1 & 89.6 & 90.8 & 89.2 & 89.2 & 89.7 & 89.8 & 90.2 & 90.1 & 89.8 & 89.4 & 89.5 & 88.7 & 88.4 & 88.8 & 90.1 & 96.7 & 94.4 & 87.0 & 89.0 & 92.5 \\ 90.5 & 90.2 & 91.4 & 89.8 & 89.8 & 90.8 & 90.3 & 91.0 & 90.4 & 90.7 & 90.5 & 90.6 & 90.4 & 8.1 & 90.0 & 91.6 & 95.8 & 95.0 & 86.9 & 9.3 & 93.6\end{array}$

${ }^{a}$ The sequences used in the similarity calculations were obtained from the Ribosomal Database Project, version 5.0 (20, 27). A total of 1.261 unambiguous bases were used in the analysis. 


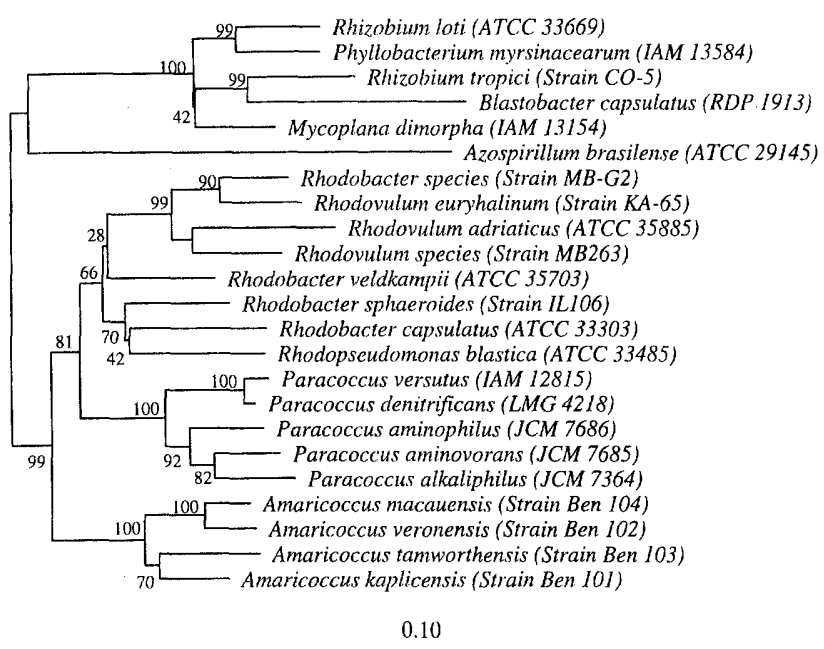

FIG. 3. Phylogenetic tree showing the positions of strains Ben $101^{\mathrm{T}}$, Ben $102^{\mathrm{T}}$, Ben $103^{\mathrm{T}}$, and Ben $104^{\mathrm{T}}$, which are members of the $\alpha$ subclass of the Proteobacteria. The tree was derived from the distance matrix shown in Table 3.

Rhodobacter $(14,15)$ (average level of similarity, 91\%). In addition, the morphology, $\mathrm{G}+\mathrm{C}$ contents, and phenotypic characteristics of these strains clearly distinguish them from members of the genera Rhodobacter, Rhodovulum, and Paracoccus, as shown in Table 4. In this study we determined the taxonomic positions of these four morphologically similar strains, all of which were obtained from activated sludge. Based on the results of extensive phenotypic characterization, numerical taxonomy, and phylogenetic analyses, these gramnegative cocci are different from all previously described organisms. They should be placed in a new genus of the class Gracilicutes and are clearly not members of the genus Meth- anosarcina in the Archaea, as suggested originally by Cech and Hartman (8). We propose that these isolates should be placed in the genus Amaricoccus gen. nov. Even though they exhibit high overall levels of similarity in their $16 \mathrm{~S}$ rDNA sequences, especially the $16 \mathrm{~S}$ rDNA sequences of Ben $102^{\mathrm{T}}$ and Ben $104^{\mathrm{T}}$ (Table 3), strains Ben $101^{\mathrm{T}}$, Ben $102^{\mathrm{T}}$, Ben $103^{\mathrm{T}}$, and Ben $104^{\mathrm{T}}$ are sufficiently different phenotypically from each other to warrant description as members of new species of the genus Amaricoccus; these strains are described as members of Amaricoccus kaplicensis, Amaricoccus veronensis, Amaricoccus tamworthensis, and Amaricoccus macauensis, respectively.

Description of Amaricoccus gen. nov. Amaricoccus (A.ma'ri. coc.cus. Gr. n. amara, sewage duct; Gr. n. coccus, grain; L. n. Amaricoccus, spherical cells from sewage ducts). Large, gramnegative, non-spore-forming cocci (mean cell diameter, 1.3 to $1.8 \mu \mathrm{m}$ ) that are usually arranged in tetrads. Cells are nonmotile. They do not store polyphosphate granules either in situ or in axenic culture. Amaricoccus spp. possess the following enzymes: alkaline phosphatase, esterase, esterase-lipase, lipase, leucine arylamidase, valine arylamidase, acid phosphatase, naphthol-AS-BI-phosphohydrolase, and $\alpha$-glucosidase. They lack the enzymes cystine arylamidase, trypsin, chymotrypsin, $\alpha$-galactosidase, $\beta$-galactosidase, $\beta$-glucuronidase, $\beta$-glucosidase, $N$-acetyl- $\beta$-glucosaminidase, $\alpha$-mannosidase, $\alpha$-fucosidase, lysine decarboxylase, ornithine decarboxylase, and arginine dihydrolase (at both 24 and $48 \mathrm{~h}$ ). The following substrates are utilized: dextrin, L-arabinose, D-arabitol, cellobiose, D-fructose, L-fucose, D-galactose, $\alpha$-D-glucose, $m$-inositol, maltose, $D$-mannitol, D-mannose, D-psicose, L-rhamnose, D-sorbitol, sucrose, D-trehalose, turanose, xylitol, methyl pyruvate, monomethyl succinate, $\alpha$-hydroxybutyric acid, $\beta$-hydroxybutyric acid, $\alpha$-ketobutyric acid, DL-lactic acid, succinic acid, succinamic acid, D-alanine, L-alanine, L-asparagine, L-glutamic acid, maltotriose, palatinose, D-ribose, salicin, D-tegatose, D-xylose, D-lactic acid methyl ester, L-lactic acid, D-malic acid, L-malic acid, methyl succinate, pyruvic acid, $N$-acetyl-L-glutamic acid, and adeno-

TABLE 4. Differential characteristics of Amaricoccus gen. nov. and the most closely related genera in the $\alpha$ subdivision of the Proteobacteria

\begin{tabular}{|c|c|c|c|c|}
\hline Characteristic & Amaricoccus & Rhodovulum ${ }^{a}$ & Rhodobacter ${ }^{b}$ & Paracoccus $^{c}$ \\
\hline Cell size $(\mu \mathrm{m})$ & $1.3-1.8$ & $0.6-1.0$ & $0.5-1.2$ & $1.0-1.3$ \\
\hline Cell shape & Cocci (arranged in tetrads) & Ovoid to rod shaped & Ovoid to rod shaped & Coccoid to short rods \\
\hline Motility & Nonmotile & $\begin{array}{l}\text { Motile (nonmotile species } \\
\text { have been reported) }\end{array}$ & $\begin{array}{l}\text { Motile (nonmotile species } \\
\text { have been reported) }\end{array}$ & Nonmotile \\
\hline Mode of respiration & Aerobic & Anaerobic, aerobic & Anaerobic & Aerobic \\
\hline $\mathrm{G}+\mathrm{C}$ content $(\mathrm{mol} \%)$ & $51-63$ & $62-69$ & $64-70$ & $64-67$ \\
\hline Habitat & Activated sludge, sewage & $\begin{array}{l}\text { Marine or hypersaline } \\
\text { environments }\end{array}$ & $\begin{array}{l}\text { Freshwater and terrestrial } \\
\text { environments }\end{array}$ & Soil, sewage \\
\hline Growth physiology & Chemoheterotroph & Photoheterotroph & $\begin{array}{l}\text { Photoautotroph, photo- } \\
\text { heterotroph }\end{array}$ & $\begin{array}{l}\text { Autotroph, chemo- } \\
\text { heterotroph }\end{array}$ \\
\hline \multicolumn{5}{|l|}{ Substrate utilization ${ }^{d}$} \\
\hline D-Fructose & + & + & V & + \\
\hline Glucose & + & $\mathrm{V}$ & + & + \\
\hline Mannitol & + & - & V & + \\
\hline L-Glutamic acid & + & - & $t^{e}$ & + \\
\hline D-Mannose & + & - & NA & + \\
\hline D-Sorbitol & + & - & NA & + \\
\hline Sucrose & + & - & NA & + \\
\hline L-Leucine & - & + & NA & + \\
\hline L-Histidine & - & NA & NA & + \\
\hline L-Rhamnose & + & NA & NA & - \\
\hline L-Arabinose & + & W & NA & NA \\
\hline
\end{tabular}

${ }^{a}$ Data from references 12 and 13 .

${ }^{b}$ Data from references 14 and 15 .

${ }^{c}$ Data from references 18 and 37

${ }^{d}+$, positive; -, negative; W, weakly positive; V, variable; NA, no data available.

${ }^{e}$ Rhodobacter adriaticus does not utilize L-glutamic acid. 
sine. The following substrates are not utilized: $\alpha$-cyclodextrin, $N$-acetyl-D-galactosamine, i-erythritol, $\alpha$-D-lactose, lactulose, D-raffinose, D-glucosaminic acid, D-saccharic acid, sebacic acid, L-alanyl-glycine, glycyl-L-aspartic acid, L-histidine, L-leucine, Lornithine, L-pyroglutamic acid, uridine, inulin, amygdalin, $\alpha$ methyl-D-galactoside, $\beta$-methyl-D-mannoside, sedoheptulosan, stachyose, and UMP. Growth occurs at temperatures between 20 and $37^{\circ} \mathrm{C}$ and at $\mathrm{pH}$ values between 5.5 and 9.0. Oxidase positive. The DNA base compositions range from 51 to 63 $\mathrm{mol} \% \mathrm{G}+\mathrm{C}$. The natural habitat is activated sludge. The type species is Amaricoccus kaplicensis.

Description of Amaricoccus kaplicensis sp. nov. Amaricoccus kaplicensis (ka.plic.en'sis. M. L. adj. kaplicensis, referring to Kaplice, Czech Republic, the source of the type strain). The cells are pleomorphic and colonies are mucoid on GS agar. The distinctive features of this species are that it utilizes Dgalactoside acid lactone and $\alpha$-ketovaleric acid and does not utilize gentiobiose, $\beta$-methyl-D-glucoside, inositol, and lactamide. It also reduces nitrate to nitrite. The $\mathrm{G}+\mathrm{C}$ content is about $56 \mathrm{~mol} \%$. The mean cell diameter is $1.6 \mu \mathrm{m}$. The type strain, strain Ben 101, has been deposited in the Australian Collection of Microorganisms, University of Queensland, Brisbane, Australia, as strain ACM 5099.

Description of Amaricoccus tamworthensis sp. nov. Amaricoccus tamworthensis (tam.worth.en'sis. M. L. adj. tamworthensis, referring to Tamworth, Australia, the source of the type strain). The main distinctive feature of this species is the interconnecting fibril network that joins individual tetrad cells. The characteristics which differentiate this organism from other Amaricoccus species include the fact that it utilizes Tween 40, D-melibiose, D-galacturonic acid, and $\alpha$-ketoglutaric acid. However, it does not utilize glycogen, acetic acid, formic acid, bromosuccinic acid, alaninamide, L-aspartic acid, inosine, thymidine, phenylethylamine, arbutin, or $2^{\prime}$-deoxyadenosine. The $\mathrm{G}+\mathrm{C}$ content is about $51 \mathrm{~mol} \%$. The mean cell diameter is $1.8 \mu \mathrm{m}$. The type strain, strain Ben 103, has been deposited in the Australian Collection of Microorganisms, as strain ACM 5097.

Description of Amaricoccus macauensis sp. nov. Amaricoccus macauensis (ma.cau.en'sis. M. L. adj. macauensis, referring to Macau, the source of the type strain). This species is distinguished from the other three Amaricoccus species by the fact that it utilizes D-glucuronic acid, citrate, $p$-hydroxyphenylacetate, itaconate, malonate, quinic acid, glucuronamide, $\beta$-methyl-D-galactoside, hydroxy-L-proline, L-phenylalanine, $\gamma$-aminobutyric acid, putrescine, 2-aminoethanol, and DL- $\alpha$-glycerol phosphate. It possesses lysine decarboxylase. The $\mathrm{G}+\mathrm{C}$ content is about $63 \mathrm{~mol} \%$. The mean cell diameter is $1.3 \mu \mathrm{m}$. The type strain, strain Ben 104, has been deposited in the Australian Collection of Microorganisms as strain ACM 5096.

Description of Amaricoccus veronensis sp. nov. Amaricoccus veronensis (ve.ron.en'sis. M. L. adj. veronensis, referring to Verona, Italy, the source of the type strain). This species utilizes the following substrates: adonitol, glycyl-L-glutamic acid, 2,3 butanediol, $N$-acetylmannosamine, and $\alpha$-methyl-D-glucoside. However it does not utilize $N$-acetyl-D-galactosamine, D-gluconic acid, $\gamma$-hydroxybutyric acid, and glycerol. It is urease and catalase negative. The $\mathrm{G}+\mathrm{C}$ content is about $5 \mathrm{~mol} \%$. The mean cell diameter is $1.8 \mu \mathrm{m}$. The type strain, strain Ben 102, has been deposited in the Australian Collection of Microorganisms as strain ACM 5098.

\section{ACKNOWLEDGMENT}

We thank J. S. Cech for supplying a culture of "G" bacteria.

\section{REFERENCES}

1. Amann, R. I., W. Ludwig, and K.-H. Schleifer. 1995. Phylogenetic identification and in situ detection of individual microbial cells without cultivation. Microbiol. Rev. 59:143-169.

2. Amikam, D., and M. Benziman. 1989. Cyclic diguanylic acid and cellulose synthesis in Agrobacterium tumefaciens. J. Bacteriol. 171:6649-6655.

3. Blackall, L. L. 1994. Molecular identification of activated sludge foaming bacteria. Water Sci. Technol. 29:35-42.

4. Bond, P. L., P. Hugenholtz, J. Keller, and L. L. Blackall. 1995. Bacterial community structures of polyphosphate-removing and non-phosphate-removing activated sludges from sequencing batch reactors. Appl. Environ. Microbiol. 61:1910-1916.

5. Carucci, A., K. Lindrea, M. Majone, and R. Ramadori. 1995. Dynamics of the anaerobic utilization of organic substrates in an anaerobic/aerobic sequencing batch reactor. Water Sci. Technol. 31:35-43.

6. Cech, J. S., and P. Hartman. 1990. Glucose induced breakdown of enhanced biological phosphate removal. Environ. Technol. 11:651-656.

7. Cech, J. S. 1991. Microbial selection in anaerobic-oxic systems. Annual report. Hydrobiological Institute, Czechoslovak Academy of Sciences, Prague, Czech Republic

8. Cech, J. S., and P. Hartman. 1993. Competition between polyphosphate and polysaccharide accumulating bacteria in enhanced biological phosphate removal systems. Water Res. 27:1219-1225.

9. Eikelboom, D. H., and H. J. C. van Buijsen. 1993. Neisser stain, p. 23. In D Jenkins, M. G. Richard, and G. T. Daigger (ed.), Manual on the causes and control of activated sludge bulking and foaming, 2nd ed. Lewis Publishers, Inc., Boca Raton, Calif.

10. Felsenstein, J. 1993. PHYLIP (phylogenetic inference package), version 3.51c. Department of Genetics, University of Washington, Seattle.

11. Fukase, T., M. Shibata, and Y. Miyaji. 1984. The role of an anaerobic stage on biological phosphorus removal. Water Sci. Technol. 17:69-80.

12. Hiraishi, A., and Y. Ueda. 1994. Intrageneric structure of the genus Rhodobacter: transfer of Rhodobacter sulfidophilus and related marine species to the genus Rhodovulum gen. nov. Int. J. Syst. Bacteriol. 44:15-23.

13. Hiraishi, A., and Y. Ueda. 1995. Isolation and characterization of Rhodovulum strictum sp. nov. and some other purple nonsulfur bacteria from colored blooms in tidal and seawater pools. Int. J. Syst. Bacteriol. 45:319-326.

14. Imhoff, J. F. 1989. Genus Rhodobacter Imhoff, Trüper and Pfennig 1984 342 vp, p. 1668-1672. In J. T. Staley, M. P. Bryant, N. Pfennig, and J. G. Holt (ed.), Bergey's manual of systematic bacteriology, vol. 3. The Williams and Wilkins Co., Baltimore, Md.

15. Imhoff, J. F and H. G. Trüper. 1992. The genus Rhodospirillum and related genera, p. 2141-2155. In A. Balows, H. G. Trüper, M. Dworkin, W. Harder, and K.-H. Schleifer (ed.), The prokaryotes, 2nd ed. Springer-Verlag, New York, N.Y.

16. Jukes, T. H., and C. R. Cantor. 1969. Evolution of protein molecules, p. 21-132. In H. N. Munro (ed.), Mammalian protein metabolism, vol. 3. Academic Press, New York, N.Y.

17. Kataoka, N., T. Tokiwa, Y. Tanaka, K. Takeda, and T. Suzuki. 1996. Enrichment culture and isolation of slow-growing bacteria. Appl. Microbiol. Biotechnol. 45:771-777.

18. Kocur, M. 1984. Genus Paracoccus M. Kucor, p. 399-402. In J. T. Staley, M. P. Bryant, N. Pfennig, and J. G. Holt (ed.), Bergey's manual of systematic bacteriology, vol. 1. The Williams and Wilkins Co., Baltimore, Md.

19. Liu, W.-T., T. Mino, K. Nakamura, and T. Matsuo. 1996. Glycogen accumulating population and its anaerobic substrate uptake in anaerobic-aerobic activated sludge without biological phosphorus removal. Water Res. 30:75-82.

20. Maidak, B. L., G. J. Olsen, N. Larsen, R. Overbeek, M. J. McCaughey, and C. R. Woese. 1996. The Ribosomal Database Project (RDP). Nucleic Acids Res. 24:82-85.

20a.Maszenan, A. M. Unpublished data

21. Matsuzawa, Y., and T. Mino. 1991. Role of glycogen as an intracellular carbon reserve of activated sludge in the competitive growth of filamentous and non-filamentous bacteria. Water Sci. Technol. 23:899-905.

22. Matthysse, A. G., S. White, and R. Lightfoot. 1995. Genes required for cellulose synthesis in Agrobacterium tumefaciens. J. Bacteriol. 177:1069-1075.

23. Mino, T., H. Satoh, and T. Matsuo. 1994. Metabolism of different bacterial populations in enhanced biological phosphate removal processes. Water Sci. Technol. 29:67-70.

24. Mino, T., W.-T. Liu, F. Kurisu, and T. Matsuo. 1995. Modelling glycogen storage and denitrification capability of microorganisms in enhanced biological phosphate removal processes. Water Sci. Technol. 31:25-34.

25. Muyzer, G., and N. B. Ramsing. 1995. Organization of microbial communities. Water Sci. Technol. 32:1-9.

26. Nakamura, K., A. Hiraishi, Y. Yoshimi, M. Kawaharasaki, K. Masuda, and Y. Kamagata. 1995. Microlunatus phosphovorus gen. nov., sp. nov., a new gram-positive polyphosphate-accumulating bacterium isolated from activated sludge. Int. J. Syst. Bacteriol. 45:17-22.

27. Olsen, G. J., N. Larsen, and C. R. Woese. 1991. The Ribosomal RNA Database Project. Nucleic Acids Res. 19:2017-2021.

28. Owen, R. J., and S. P. Lapage. 1976. The thermal denaturation of partly 
purified bacterial deoxyribonucleic acid and its taxonomic applications. J. Appl. Bacteriol. 41:335-340.

29. Painter, H. A. 1983. Metabolism and physiology of aerobic bacteria and fungi, p. 11-75. In C. R. Curds and H. A. Hawks (ed.), Ecological aspects of used-water treatment, vol. 2. Biological activities and treatment processes. Academic Press, London, Great Britain.

30. Patel, B. K. C., K. T. Andrews, B. Ollivier, R. A. Mah, and J. L. Garcia. 1995. Reevaluating the classification of Halobacteroides and Haloanaerobacter species based on sequence comparisons of the $16 \mathrm{~S}$ ribosomal RNA gene. FEMS Microbiol. Lett. 134:115-119.

31. Randall, A. A. 1994. Ph D. thesis. Auburn University, Auburn, Ala.

32. Seviour, E. M., C. William, B. De Grey, J. Soddell, R. J. Seviour, and K. C Lindrea. 1994. Studies on filamentous bacteria from Australian activated sludge plants. Water Res. 28:2335-2342.

33. Shiba, T. 1991. Roseobacter litoralis gen nov., sp. nov., and Roseobacter denitrificans sp. nov., aerobic pink-pigmented bacteria which contain bacteriochlorophyll a. Syst. Appl. Microbiol. 14:140-145.

34. Shiba, T. 1992. The genus Roseobacter, p. 2156-2159. In A. Balows, H. G. Trüper, M. Dworkin, W. Harder, and K.-H. Schleifer (ed.), The prokaryotes, 2nd ed. Springer-Verlag, New York, N.Y.

35. Skerman, V. B. D. 1968. A new type of micromanipulator and microforge J. Gen. Microbiol. 54:287-297.

36. Smibert, R. M., and N. R. Krieg. 1994. Phenotypic characterization, p 607-654. In P. Gerhardt, R. G. E. Murray, W. A. Wood, and N. R. Krieg (ed.), Methods for general and molecular bacteriology. American Society for Microbiology, Washington, D.C.
37. Sneath, P. H. A., and R. R. Sokal. 1973. Numerical taxonomy: the principles and practice of numerical classification. W.H. Freeman, San Francisco, Calif.

37a.Soddell, J. A. Unpublished data.

38. Vandamme, P., B. Pot, M. Gillis, P. De Vos, K. Kersters, and J. Swings. 1996 Polyphasic taxonomy, a consensus approach to bacterial systematics. Microbiol. Rev. 60:407-438.

39. Van Verseveld, H. W., and A. H. Stouthamer. 1992. The genus Paracoccus, p. 2321-2334. In A. Balows, H. G. Trüper, M. Dworkin, W. Harder, and K.-H Schleifer (ed.), The prokaryotes, 2nd ed. Springer-Verlag, New York, N.Y.

40. Wagner, M., R. Erhart, W. Manz, R. Amann, H. Lemmer, D. Wedi, and K.-H. Schleifer. 1994. Development of an rRNA-targeted oligonucleotide probe specific for the genus Acinetobacter and its application for in situ monitoring in activated sludge. Appl. Environ. Microbiol. 60:792-800.

41. Wanner, J. 1994. Activated sludge bulking and foaming control. Technomic Publishing Co., Inc., Lancaster, Penn.

42. Williams, T. M., and R. F. Unz. 1985. Isolation and characterization of filamentous bacteria present in bulking activated sludge. Appl. Microbiol. Biotechnol. 22:273-282.

43. Winker, S., and C. R. Woese. 1991. A definition of the domains Archaea Bacteria and Eucarya in terms of small ribosomal RNA characteristics. Syst Appl. Microbiol. 14:305-310.

44. Yoshimi, Y., A. Hiraishi, and K. Nakamura. 1996. Isolation and characterization of Microsphaera multipartita gen. nov., sp. nov., a polysaccharideaccumulating gram-positive bacterium from activated sludge. Int. J. Syst. Bacteriol. 46:519-525 